УДК: $81 ' 255.4(=111:=161.2)$

О. А. Остроушко

\title{
ЛЕКСИЧНІ ТРАНСФОРМАЦІЇ ПРИ ПЕРЕКЛАДІ АНГЛІЙСЬКИХ ІНФОРМАЦІЙНИХ ТЕКСТІВ УКРАЇНСЬКОЮ МОВОЮ
}

\begin{abstract}
Остроушко О. А. Лексичні трансформації при перекладі англійських інформаційних текстів українською мовою.

У статті визначено й описано основні лексичні перекладацькі трансформації, застосовувані при перекладі англійських інформаційних текстів українською мовою. Доведено, що спосіб перекладу лексичних елементів залежить від особливостей лексико-семантичних систем мов оригіналу й перекладу, функціональних i стилістичних характеристик слів, національно-культурних чинників.

Ключові слова: лексична трансформація, конкретизація значення, генералізація значення, смисловий розвиток, антонімічний переклад, додавання й вилучення слова, цілісне переосмислення.
\end{abstract}

Остроушко О. А. Лексические трансформации при переводе английских информационных текстов на украинский язык.

В статье определены и описаны основные лексические переводческие трансформации, которые используются при переводе английских информационных текстов на украинский язык. Доказывается, что способ перевода лексических элементов зависит от особенностей лексико-семантических систем языков оригинала и перевода, функциональных и стилистических характеристик слов, национально-культурных факторов.

Ключевые слова: лексическая трансформация, конкретизация значения, генерализация значения, смысловое развитие, антонимический перевод, добавление и удаление слова, целостное переосмысление.

Ostroushko O. A. Lexical transformations when translating English informative texts into Ukrainian.

The main lexical translation transformations used during translating English informative texts into Ukrainian are revealed and described. The author argues that a way of translating lexical elements depends on peculiarities of lexical-semantic systems of original and target languages, functional and stylistic features of words, national-cultural factors.

Key words: lexical transformation, concretization of meaning, generalization of meaning, sense development, antonymous translation, addition and removal of word, integral rethinking.

При перекладі інформаційних текстів виникає необхідність застосування лексичних перекладацьких трансформацій, під якими розуміють «закономірні заміни словникових відповідників у процесі перекладу» [4, с. 101], «різного роду зміни лексичних елементів мови оригіналу під час перекладу з метою адекватної передачі їх семантичних, стилістичних і прагматичних характеристик із врахуванням норм мови перекладу та мовленнєвих традицій культури мови перекладу» [3, с. 39]. Основними такими трансформаціями $є$ конкретизація значень, генералізація значень, смисловий розвиток, антонімічний переклад, додавання й вилучення слова, цілісне переосмислення. 
Лексичний елемент перекладається не окремо, а в сукупності його контекстуальних зв'язків i функціональних характеристик, що й демонструє, зокрема, переклад багатозначних слів. Знання словникових відповідників $\epsilon$ необхідною, але недостатньою умовою адекватного перекладу лексики, оскільки контекст часто диктує необхідність відхилення від словникових відповідників. Звичайно, все багатоманіття контекстів не можна зафіксувати у словнику, навіть на рівні словосполучень. Тому одна 3 головних трудностей перекладу необхідність знайти конкретне значення слова чи словосполучення, відсутнє в словнику, але єдино доречне в певному контексті. Важливим способом вибору контекстуального відповідника слова $є$ перекладацька лексична трансформація конкретизації значення, що зумовлена розбіжностями у функціональних характеристиках словникових відповідників лексичних елементів оригіналу та традиціях мовлення [3, с. 39; 4, с. 101]. «Конкретизація значення - це лексична трансформація, внаслідок якої слово (термін) ширшої семантики в оригіналі замінюється словом (терміном) вужчої семантики» [3, с. 39]. Наприклад: It found depression was less common among parents whose children lived further away, compared to parents whose children lived locally. Depression was highest among parents of poorer families with all their children still living in the local area, the study showed (DT, 01.07.09) - «3'ясовано, що депресія загалом менше властива тим батькам, чиї діти живуть досить далеко, аніж тим, чиї діти залишаються жити поруч. Дослідження виявило, що найвищий рівень депресії серед людей у бідних сім'ях, де всі діти проживають неподалік від батьків». Конкретизація значення, як це видно з наведеного прикладу, вимагає також низки граматичних трансформацій.

Зрозуміло, що цей спосіб перекладу частіше застосовують тоді, коли перекладаються слова із дуже широким значенням на кшталт thing, matter, piece, affair, unit, claim, concern, fine, good, to be, to do, to get, to come тощо [3, c. 40]: The world's first synthetic brain could be built within 10 years, giving us an unprecedented insight into the nature of consciousness and our perception of reality (Guardian $(\mathrm{G}), 23.07 .09)$ - «Перший у світі синтетичний мозок міг би бути створений протягом десять років, даючи нам безпрецедентну можливість осягнути сутність свідомості й нашого сприйняття дійсності»; The Taliban have confirmed on their website that they are holding an American soldier the US military had earlier described as possibly being in enemy hands (G, 06.07.09) - «Талібан на своєму веб-сайті підтвердив, що вони утримують у полоні американського солдата, якого раніше американські військові оголосили таким, що, можливо, перебуває в руках ворога»; A GP and a six-year-old girl have died after contracting swine flu, taking the number of UK deaths linked to the virus to 17, officials announced today ( $\mathrm{G}, 13.07 .09)$ - «Сьогодні офіційно оголошено, що від 
свинячого грипу померли сімейний лікар і шестирічна дівчинка, що довело число померлих від вірусу в Об’єднаному Королівстві до сімнадцяти».

Генералізація значення слова - трансформація, протилежна за напрямком конкретизації. Унаслідок генералізації слово 3 вужчим значенням, що перекладається, замінюється в перекладі на слово із ширшим значенням, нерідко гіпонімом [3, с.45]. При цьому слід бути обачним, щоб уникнути втрати точності інформації: A grandmother survived 11 days at the bottom of a ravine after getting lost on a rambling holiday in the Spanish Pyrenees by sipping rain water and nibbling wild herbs (DT, 09.07.09) - «Заблукавши під час прогулянки в Іспанських Піренеях, жінка провела 11 днів на дні ущелини, п'ючи лише дощову воду й харчуючись дикими рослинами». Англійське grandmother, як його українські відповідники баба або пестливе бабуся, означають передусім «мати батька або матері» [2; 6; 7]. Уживання цих лексем щодо жінки похилого віку (або в українській мові й щодо жінки взагалі) позначене відтінком розмовності. Стилістичні норми англійського інформаційного мовлення цілком припускають уживання розмовних елементів, але це не властиве українським інформаційним текстам, що й зумовлює в розглядуваному контексті застосування прийому генералізації. Інша англійська лексема - survive - українськими словниковими відповідниками має «переживати (сучасників тощо); витримати, перенести, пережити (щось); лишитися живим; продовжувати існувати; вціліти» [5]. Зрозуміло, що повідомлення інформує про виживання в умовах дикої природи, але українське виживати «залишатися живим, незважаючи на небезпеку, тяжке захворювання, скрутні умови існування і т. ін.» [2], як правило, поєднується 3 обставинами на позначення тривалого нечітко окресленого часового проміжку (виживати всі изі роки, довгі місяці, увесь час тощо). У наведеному ж уривку йдеться про точну кількість днів, що й зумовлює вживання слова з більш широким значенням. Ще дві англійські лексеми nibbling sipping - у своєму лексичному значенні мають семи невеликої кількості: nibble - «take small quick bites: to take a series of small quick bites at something, or eat something in a series of small quick bites», sip - «drink slowly in very small amounts: to drink something slowly, taking only a small amount at a time» [7]. Ці слова перекладаються описово: nibble - відкушувати маленькими шматочками; sip - пити маленькими ковтками [5]. Можна дібрати й однослівні відповідники: так, значення «відокремлювати невеликі частинки чого-небудь, захоплюючи, здавлюючи зубами» має українське дієслово кусати [2], але воно не сполучається 3 іменниками трава або рослина, а саме про дикі рослини мовиться в тексті. Крім того, по-українськи вкусити чи відкусити що-небудь не значить його з їсти. Значення «пити, перев. невеликими ковтками й видаючи при цьому характерні звуки» має українське слово сьорбати [2], але це розмовна лексема, вживання яких не бажане в інформаційному українському мовленні. 
Як бачимо, застосування прийому генералізації зумовлюється різними стилістичними нормами англійської та української мов, відмінностями синтагматичної сполучуваності відповідників в обох мовах, а також розбіжностями в лексико-семантичних системах мов. Щодо останнього чинника, прикладом може бути й таке речення: The toddler was strangled by the snake in the town of Oxford... (DT, 01.07.09) - «Змія задушила дитину в містечку Оксворд...». Англійське toddler означає «маленька дитина, яка вчиться ходити»: «young child: a young child who is learning to walk» [6; 7]. Українська мова не має лексеми, яка б називала дитину саме в цей період іiі розвитку.

Смисловий розвиток є таким прийомом контекстуальної заміни, коли в перекладі використовується слово, значення якого є логічним розвитком значення слова, що перекладається. Подібні відхилення від «букви» оригіналу іноді необхідні для досягнення адекватності перекладу, оскільки в мовах оригіналу й перекладу можуть діяти різні мовленнєві норми та існувати різні традиції мовлення [3, с. 28]. Звичайно, послуговуватися подібним прийомом слід дуже обачно, оскільки значний семантичний розвиток значення слова, що перекладається, може призвести до викривлення змісту оригіналу й порушення адекватності перекладу [3, с. 29]. Смисловий розвиток, так само як i iнші види лексичних трансформацій, стосується не окремо взятого слова, а мінімум словосполучення, певної смислової групи. Логічно, що при подібній трансформації відбуватимуться й граматичні видозміни конструкцій. Найпоширеніші випадки смислового розвитку, за Я. Рецкером, вкладаються в схему причина $\rightarrow$ процес $\rightarrow$ наслідок. Відповідно, можуть бути такі його різновиди: 1) заміна процесу його причиною, 2) заміна процесу його наслідком, 3) заміна причини процесом, 4) заміна наслідку процесом, 5) заміна наслідку причиною, 6) заміна причини наслідком (під процесом мають на увазі виражену дієсловом-присудком дію чи стан) [4, с. 104-105]. Наприклад: More than two-thirds of voters say the Scottish Parliament has achieved little or nothing in first decade of devolution, a new poll has revealed (DT, 01.07.09) - «Нове соціологічне опитування виявило, що більш ніж дві третини виборців вважають, що Шотландський парламент не зробив майже нічого за десять років своєї роботи»; Violators can also face up to three years in priso (DT, 09.07.09) - «Порушникам загрожує до трьох років в'язниці» (можливий і варіант «позбавлення волі»).

Антонімічний переклад - перекладацька трансформація, що полягає в заміні форми слова або словосполучення на протилежну (позитивної - на негативну й навпаки). Зміст одиниці, котра перекладається, залишається в основному подібним. В. Карабан зауважує, що термін «антонімічний переклад» $є$ неточним, оскільки слово, що перекладається, не замінюється на антонім у мові перекладу, а змінює лише форму на протилежну. Саме тому дослідник пропонує назвати цю трансформацію «формальною негативацією» [3, с. 30], якої засвідчено три види: 1) негативація - слово 
або словосполучення без формально вираженої суфіксом або часткою заперечувальної семи замінюється в перекладі на слово з префіксом не- або словосполученням із часткою не; 2) позитивація - слово або словосполучення 3 формально вираженою заперечувальною семою замінюється в перекладі на слово або словосполучення, яке не містить формально вираженого негативного компонента; 3) анулювання двох наявних у реченні негативних семантичних компонентів. Наприклад: Filming has not been disrupted (Observer (Obs), 05.07.09) - «Зйомки фільму тривають»; Schools, for instance, will only be closed if too many teachers are off sick to keep classes going... (G, 07.07.09) - «Школи, наприклад, будуть закриватися тільки якщо більшість учителів через хворобу не зможуть продовжувати проводити заняття»; Pilots on selected trans-oceanic routes are due to test the system... as early as next year (G, 09.07.09) - «Пілоти на вибраних трансатлантичних маршрутах мають протестувати систему... не раніше ніж на наступний рік»; Professor John Hills, from the London School of Economics, said health inequalities had not improved despite significant government attention (G, 09.07.09) - «Професор Джон Хіллс із Лондонської школи економіки заявив, що ця різниця [ідеться про різну середню тривалість життя англійців, котрі проживають у різних частинах країни] не зникла навіть незважаючи на значну увагу з боку уряду».

Часто прийом формальної негативації застосовується при перекладі складних речень, що містять заперечувальну частку not і сполучник until або unless, наприклад: NHS East of England said a swab test confirmed Day had also contracted the HINI virus, but the exact cause of death will remain unknown until the coroner's report $(\mathrm{G}, 13.07 .09)$ - «Державна служба охорони здоров'я східної частини Англії заявила, що аналіз підтвердив, що Дей був заражений вірусом H1N1, але точна причина смерті буде встановлена після розтину». При перекладі наведеного уривку мусимо застосувати також прийом смислового розвитку, що зумовлено вживанням в англійському реченні лексеми coroner, яка є словом-реалією: коронер «у Великій Британії, США та деяких інших країнах - судовий слідчий, що провадить слідство у випадках підозрілої або наглої смерті, після чого передає справу до суду» [2]. Саме у звіті коронера зазначається причина смерті людини. В Україні висновки щодо причини підозрілої смерті робить бюро судово-медичної експертизи, але в мовленнєвій практиці не прийнято говорити про висновок чи звіт експертизи, натомість усталився вислів після розтину. Відповідно, маємо, за Я. Рецкером, заміну наслідку процесом.

Досить частотними при перекладі інформаційних текстів виявилися трансформації додавання й вилучення слів. Трансформація додавання полягає у введенні в переклад лексичних елементів, що відсутні в оригіналі, з метою правильної передачі смислу речення (оригіналу), що перекладається, та/ або дотримання мовленнєвих і мовних норм, що існують у культурі мови перекладу [3, с. 48]. Відповідно, вилучення - 
виправдане з мочки зору адекватності перекладу, передусім норм мови перекладу, усунення в тексті перекладу тих плеонастичних або тавтологічних лексичних елементів, які за нормами мови перекладу $\epsilon$ частинами імпліцитного смислу тексту [3, с. 50]. Зрозуміло, що подібні трансформації вимагають від перекладача значної уваги, щоб у перекладі не було спотворено або зменшено обсяг оригінальної інформації. Зазначені прийоми зумовлені передусім розбіжностями лексико-семантичних систем обох мов, відсутністю однослівних відповідників. Інший важливий чинник, який визначає застосування додавання чи вилучення слів, - потреби контексту. У тому чи іншому контексті лексема може актуалізувати імпліцитні смисли, пов'язані 3 національно-культурними конотаціями, епідигматичними відношеннями між словами тощо. Це, зі свого боку, вимагає додаткового пояснення при перекладі.

Додавання слів у переважній більшості випадків диктується застосуванням описового перекладу [4, с. 114]: Such systems allow elderly or handicapped people to interact with the world through signals from their brains, without having to give voice commands... (DT, 01.07.09) - «Подібні системи дозволять старим людям або людям із фізичними чи розумовими вадами взаємодіяти 3 навколишнім світом за допомогою сигналів мозку, не вдаючись до голосових команд...»; According to the latest estimates of the India Meteorological Department, rainfall during this year's monsoon has so far been 43 per cent below the long-term average (DT, 14.07.09) - «Згідно з останніми оцінками Індійського метеорологічного відомства, кількість опадів протягом цьогорічного мусону на цей час на 43 \% нижча за звичайну середню величину».

Поява додаткових лексем також пов'язується 3 мовленнєвими нормами мови перекладу: Tens of thousands of people are expected to lose their jobs as a result of the law, which was signed in 2006 by then-president Vladimir Putin (DT, 01.07.09). Англійський вираз as a result of має словниковий український відповідник «унаслідок» [5], але реченнєвий контекст унеможливлює подібний переклад: не можна втратити роботу «унаслідок закону», тому в українському перекладі варто сказати «унаслідок прийняття закону» або, краще, «після прийняття закону» чи «після того, як закон вступить у силу»: «Очікується, що десятки тисяч людей втратять роботу після того, як цей закон, підписаний у 2006 році тодішнім президентом Владіміром Путіним, вступить у силу».

Відсутність однослівного відповідника може зумовити необхідність цілісного переосмислення вислову: The quake was followed by eight aftershocks (DT, 09.07.09). Англійське aftershock означає «small earthquake: a small earthquake, usually one of several, that follows a larger one» [7], тобто незначний підземний поштовх після основного землетрусу [5]. Сказати українською, що «землетрус продовжився ще вісьмома невеликими поштовхами» буде синтаксичною та стилістичною помилкою, 
тому необхідно переосмислити вислів: «Після основного поштовху сталося ще вісім слабких».

Вилучення слів у більшості випадків пов'язане 3 необхідністю уникнути тавтології чи плеоназму при перекладі: Despite several attempts on her life, she carried on with her work until she was shot dead on her doorstep in Moscow (G, 16.07.09) - «Незважаючи на кілька замахів на своє життя, вона продовжувала роботу, поки не була застрелена на порозі свого будинку в Москві»; ... a committee has unanimously rejected the plans to sounds of cheering and applause (DT, 02.07.09) - «Комітет одностайно під схвальні вигуки відхилив проекти»; Investigators are still uncertain why the Airbus A330 fell from the sky after taking off from Brazil (DT, 09.07.09) «Слідчі ще не можуть точно назвати причину падіння Аеробуса А-330 відразу після зльоту в Бразилії» (DT, 09.07.09).

Зрозуміло, що при перекладі випускаються службові слова, як-от артиклі, допоміжні дієслова, прийменники, що є природнім результатом відмінностей граматичного ладу обох мов: The virus has killed at least 163 people and infected 14,750 across Sri Lanka so far this year, more than double the cases in all of last year ( $\mathrm{G}, 07.07 .09)$ - «Вірус убив щонайменше 163 людини й інфікував 14750 у Шрі-Ланка протягом цього року, що більше ніж удвоє перевищує минулорічні випадки».

Цілісне переосмислення передбачає вираження смислу сказаного на одній мові засобами іншої, які не $\epsilon$ ані словниковими, ані контекстуальними відповідниками окремих слів. Найширше застосування цей прийом отримує при перекладі різного роду стійких висловів (фразеологізмів, прислів'їв тощо). Така трансформація ставить перед перекладачем вимогу широкої та глибокої соціокультурної компетенції, глибоких знань культури й мови обох народів: Instead, it brings together heads of the world's strongest economies at an annual summit for informal discussions of the most pressing global issues with a view to increasing international cooperation (DT, 02.07.09) - «Натомість, вона [ідеться про Велику вісімку] збирає глав восьми найсильніших економічно держав на щорічний саміт для неформального обговорення нагальних глобальних проблем $з$ метою посилення міжнародного співробітництва»; The Church has been cooperating fully with the police and other agencies since the extent and seriousness of this matter came to light (DT, 02.07.09) - «Церква співпрацює $з$ поліцією та іншими агентствами, відтоді як виявилися міра й серйозність цієї справи»; I'd always had it in the back of my mind that when the time was right I'd like to have a child (DT, 14.07.09) - «У глибині душі в мене завжди була думка, що як прийде час, я би хотіла мати дитину»; Players who fell short of Wimbledon glory (G, 03.07.09) - «Гравці, котрі не досягли Уїмблдонського тріумфу». Так, англійський вислів to fall short (=to come short) означає «не вистачати, бракувати, поступатися в чомусь; не виправдати надій, сподівань, не досягти мети» [1, с. 230]. У замітці йдеться 
про спортсменів, які так i не змогли перемогти на знаменитому Уїмблдонсьокому турнірі. Це й зумовлює вибір контекстуального варіанта перекладу усталеного звороту.

Отже, при перекладі інформаційних текстів виникає необхідність застосування перекладацьких лексичних трансформацій. В опрацьованому матеріалі зафіксовано конкретизацію й генералізацію значень, смисловий розвиток, антонімічний переклад, додавання й вилучення слова, цілісне переосмислення. Це зумовлено головним чином розбіжностями в лексикограматичних системах двох мов, відмінностями їхніх стилістичних норм, правил синтагматичної сполучуваності лексем.

\section{Література}

1. Англо-український фразеологічний словник / [уклад. К. Т. Баранцев]. [3-тє вид., стер.]. - К.: Т-во «Знання», КОО, 2006. - 1056 с.

2. Великий тлумачний словник сучасної української мови / [уклад. і голов. ред. В. Т. Бусел]. - К. - Ірпінь: ВТФ „Перун”, 2002. - 1736 с. - [Електронний pecypc]. - Режим доступу: http://www.slovnyk.net/

3. Карабан В. І. Переклад англійської наукової і технічної літератури. Ч. 2. Лексичні, термінологічні та жанрово-стилістичні труднощі / В'ячеслав Іванович Карабан. - Вінниця: Нова книга, 2001. - 303 с.

4. Рецкер Я. И. Пособие по переводу с английского языка на русский / Яков Иосифович Рецкер. - Ленинград: Просвещение (Ленинградское отделение), 1973. - 199 с.

5. ABBYY Lingvo Online Dictionary [Електронний ресурс]. - Режим доступу до словника: http://lingvo.abbyyonline.com/

6. Cambridge Advanced Learner's Dictionary [Електронний ресурс]. - Режим доступу до словника: http://dictionary.cambridge.org/

7. MSN. Encarta. Dictionary [Електронний ресурс]. - Режим доступу до словника: http://encarta.msn.com/dictionary/

Стаття надійшла до редакиії 18.10.2010 p. 